\title{
Regional Differences in the Optimal Utilisation of Antenatal Care in Nigeria
}

\section{Linda Ochuole Ugalahi, Oyindamola Bidemi Yusuf, Joshua Odunayo Akinyemi, Ayo Stephen Adebowale}

Department of Epidemiology and Medical Statistics, Faculty of Public Health, University of Ibadan, Ibadan, Nigeria

\section{Email address:}

lindaugalahi@yahoo.com (L. O. Ugalahi),bidemiyusuf1@gmail.com (O. B. Yusuf), odunjoshua@yahoo.com (J. O. Akinyemi), adehamilt2008@yahoo.com (A. S. Adebowale)

\section{To cite this article:}

Linda Ochuole Ugalahi, Oyindamola Bidemi Yusuf, Joshua Odunayo Akinyemi, Ayo Stephen Adebowale. Regional Differences in the Optimal Utilisation of Antenatal Care in Nigeria. Science Journal of Public Health. Vol. 4, No. 1, 2016, pp. 43-48.

doi: $10.11648 /$ j.sjph.20160401.16

\begin{abstract}
Many maternal deaths in Nigeria are as a result of pregnancy related complications that are preventable through utilisation of antenatal care facility. The World Health Organisation recommends at least four visits to an antenatal care facility to attain full life saving potentials for pregnant women and their unborn babies. As the deadline for the Millennium Development Goals (MDG 5), which focuses on maternal health and access to health facilities) approaches, it is important to evaluate the optimal utilisation of ANC and impact of regional differences. This study determined factors that affect optimal utilisation of ANC visits. The National Demographic and Health Survey, 2013 dataset on women aged 15-49 years who had their most recent birth in the last 5 years prior the survey was used for the analysis. Optimal utilisation of ANC was defined as four or more visits. Data were analyzed using Chi-square and binary logistic regression models $(\alpha=0.05)$. Mean age of women was $29 \pm 7$ years and $53 \%$ achieved optimal utilisation. The identified predictors of optimal use of ANC were age, wealth index, number of children alive, and region among others. Women in the South-West were about $7(\mathrm{OR}=6.73,955 \% \mathrm{CI}=5.843,7.758$; $\mathrm{p}<0.001)$ times more likely to have had optimal utilisation of ANC than those in the North Central zone. This strength of relationship was retained after other socio-demographic factors were included in the regression model as control. Respondents aged 34-39 years were 2 times more likely to attain optimal utilisation of ANC facility compared to those aged 15-19 years $(\mathrm{OR}=1.50,95 \% \mathrm{CI}: 1.152,1.946)$. Respondents who belong to the richest wealth quintile were about 3 times more likely to attain optimal utilisation of $\mathrm{ANC}$ visits $(\mathrm{OR}=2.86,95 \% \mathrm{CI}: 2.162,3.775)$ compared to respondents in the poorest quintile. Optimal utilisation of ANC in Nigeria is still poor and differentials exist across the regions. Therefore, regional specific programmes targeting better utilisation of ANC visits among women should be provided particularly in the Northern part of Nigeria.
\end{abstract}

Keywords: Optimal Utilisation, Maternal Health, Maternal Mortality, Focused Antenatal Care (FANC), Health Regional Differences

\section{Introduction}

Maternal morbidity and mortality occur due to complications during pregnancy and child birth. The World Health Organization (WHO) estimates that maternal mortality is over 500000 deaths per year worldwide and 99 percent of these occur in developing countries. Nigeria accounts for about 10 percent of the world's overall maternal mortality $[1,2]$. Thus Nigeria is among countries with high burden of Maternal Mortality globally.

An estimated 800 women die every day from preventable pregnancy related causes [3]. Pregnancy related complications such as infections, eclampsia, and obstructed labour and maternal deaths may be effectively reduced through services obtainable in antenatal care services. Despite the benefits of antenatal care services, women do not utilize them optimally.

Studies have identified factors that affect the use of antenatal care facility in Nigeria. Several of these studies were done based on individual local government areas and states. [4-11]. Other studies were based on data collected at regional level, [12-14]. A few however, have utilized 
nationwide data, [15-17].

Women educational status, household wealth and distance of antenatal have been identified as factors associated with the use of antenatal care $[15,18]$. Poor communication, poverty, cultural norms, personal cost and poor power supply were identified as factors that affect the quality of care obtainable in an antenatal care facility. These reasons invariably affect the utilisation of these facilities [19]. Physical accessibility of health facilities was identified as a factor that affects utilisation of ANC services [20]. Despite several studies done on factors that affect ANC utilization, few studies have been done to identify factors that affect optimal utilization of ANC using a national representative data. As the year 2015 marks the deadline for the Millennium Development Goals (MDG 5), which focuses on improving maternal health, it is important to evaluate the utilisation of ANC and the impact of regional differences on optimal utilisation. The objectives of this study were to determine the factors associated with optimal utilisation of antenatal care and to determine the regional influence on the optimal utilisation of ANC amidst other socio-demographic factors.

\section{Methodology}

Nigeria is one of the sub-Saharan African countries located in the West African region. It covers a total area of 923,768 kilometer square. Nigeria comprises of 36 states and a Federal Capital Territory (FCT). These states are grouped into six geopolitical zones; North Central, North East, North West, South East, South-South and South West.

Data for this study was obtained from the National Demographic and Health Survey [21]. The survey made use of a population based cross-sectional study design.

The 36 states were regrouped by geopolitical location into six zones and using the 2006 Population census implementation, each locality was subdivided into Enumeration Areas (EAs). A complete list of the EAs served as the sample frame of the survey. The sampling technique for the 2013 NDHS was a stratified sample, selected at random in three stages from the sampling frame. At the first stage; each state was stratified into urban and rural areas; this resulted in a list of localities. At the second stage one enumeration area was randomly selected from a selected locality with equal probability selection, the resulting list of households served as sampling frame for the selection of households in the third stage. At the third stage 45 households were selected in every urban and rural cluster through equal probability systematic sampling using the household listing. More details can be obtained from the NDHS report [21].

For the purpose of this study a sample of 9909 women within reproductive age $15-49 y$ rs, who gave birth within the last five years and had the history of index birth, was used.

Extraction of relevant data from the NDHS dataset was performed, weighting of the data was done and simple summary statistics (percentage for categorical variables or mean for continuous variables) for all independent variables was also performed. Socio economic factors that affect utilisation of ANC were identified across the two regions of the country i. e. northern and southern regions. Chi-square test was used to investigate associations between optimal utilisation and categorical variables such as age, geopolitical zones, wealth index etc. Variables that were significant in the chi square analysis were then entered into a binary logistic regression model to further investigate the strength of these associations at 5\% level of significance. Model fit was assessed using the Hosmer Lemeshow goodness of fit test.

Number of visits to antenatal care facility was the outcome variable in this analysis, it was categorized into two; optimum use and no optimum use. Optimum use was defined as four or more visits and no optimum use defined as less than four visits [22].

$$
\text { Optimum use of ANC }=\left\{\begin{array}{c}
1 \text { if number of visits is } \geq 4 \\
0 \text { if otherwise }
\end{array}\right.
$$

The key explanatory variable was region of residence (North Central, North West, North East, South East, South West and South South). Others include; age, region, place of residence, educational level, religion, wealth index, occupation, place of antenatal, ethnicity, number of children, husband's/partner's educational level and occupation. SPSS version 20 was used for analysis.

\section{Results}

The mean age of the women was 29 years $(\mathrm{SD}=7.5)$. Women within the age group 30-34 years had the highest proportion of optimal utilisation of ANC (82.8\%), while those aged 15-19 had the least proportion $(67.6 \%)(p<0.001)$. Optimal utilisation increased with increase in educational level; respondents with higher educational level had the highest proportion compared to respondents with no education $(95.1 \%$ vs. $66.9 \%, p<0.001)$. The same pattern was observed in the wealth index of respondents, the richest had the highest proportion while the poorest had the least proportion $(93.5 \%$ vs. $61.2 \%, \mathrm{p}<0.001)$. Respondents who were employed had highest proportion of optimal utilisation of ANC while those unemployed had the lowest (80.9\% vs. $73.6 \%, \mathrm{p}<0.001$ ). (Table 1)

Table 1. Socio demographic factors associated with optimal utilisation.

\begin{tabular}{|lll|l}
\hline Variables & Optimal use\% & Total women & p-value \\
\hline Age (years) & & & \\
$15-19$ & 67.6 & 516 & \\
$20-24$ & 76.0 & 4907 & \\
$25-29$ & 78.4 & 2606 & $<0.001$ \\
$30-34$ & 82.8 & 2124 & \\
$35-39$ & 82.4 & 1604 & \\
$40-44$ & 81.8 & 836 & \\
$45-49$ & 75.2 & 314 & \\
Region & & & \\
North Central & 74.3 & 1445 & \\
North East & 65.7 & 1514 & \\
North West & 68.4 & 2637 & \\
South East & 90.7 & 1272 & \\
South South & 87.8 & 1002 & \\
\hline
\end{tabular}




\begin{tabular}{|c|c|c|c|}
\hline Variables & Optimal use $\%$ & Total women & p-value \\
\hline $\begin{array}{l}\text { South West } \\
\text { Residence }\end{array}$ & 94.9 & 2037 & \multirow{3}{*}{$<0.001$} \\
\hline Urban & 86.1 & 4428 & \\
\hline $\begin{array}{l}\text { Rural } \\
\text { Educational level }\end{array}$ & 73.5 & 5479 & \\
\hline No education & 66.9 & 3504 & \multirow{4}{*}{$<0.001$} \\
\hline Primary & 80.8 & 2606 & \\
\hline Secondary & 88.8 & 3470 & \\
\hline Higher & 95.1 & 327 & \\
\hline Religion & & & \multirow{4}{*}{$<0.001$} \\
\hline Christianity & 87.1 & 4569 & \\
\hline Islam & 72.2 & 5255 & \\
\hline Traditional & 79.5 & 83 & \\
\hline Wealth index & & & \multirow{6}{*}{$<0.001$} \\
\hline Poorest & 61.2 & 1251 & \\
\hline Poorer & 69.2 & 2047 & \\
\hline Middle & 79.1 & 2273 & \\
\hline Richer & 85.3 & 2388 & \\
\hline Richest & 93.5 & 1949 & \\
\hline Employment status & & & \multirow{3}{*}{$<0.001$} \\
\hline Unemployed & 73.6 & 2346 & \\
\hline Employed & 80.9 & 7562 & \\
\hline Ethnicity & & & \multirow{5}{*}{$<0.001$} \\
\hline Hausa & 66.8 & 2656 & \\
\hline Igbo & 91.5 & 1592 & \\
\hline Yoruba & 95.2 & 1714 & \\
\hline Others & 75.5 & 3945 & \\
\hline $\begin{array}{l}\text { Number of children } \\
\text { alive }\end{array}$ & & & \multirow{4}{*}{$<0.001$} \\
\hline $1-4$ & 80.0 & 7112 & \\
\hline $5-9$ & 77.2 & 2720 & \\
\hline 10 and Above & 61.3 & 75 & \\
\hline Place of ANC & & & \multirow{4}{*}{$<0.001$} \\
\hline At a home & 84.9 & 304 & \\
\hline $\begin{array}{l}\text { Government health } \\
\text { facility }\end{array}$ & 76.0 & 7480 & \\
\hline Private health facility & 89.2 & 2123 & \\
\hline $\begin{array}{l}\text { Husband's/partners } \\
\text { educational status }\end{array}$ & & & \multirow[t]{2}{*}{$<0.001$} \\
\hline No education & 64.9 & 2693 & \\
\hline
\end{tabular}

\begin{tabular}{llll}
\hline Variables & Optimal use\% & Total women & p-value \\
\hline $\begin{array}{l}\text { Educated } \\
\text { Husband's/partners }\end{array}$ & 84.5 & 7215 & \\
employment status & & & \\
$\begin{array}{l}\text { unemployed } \\
\text { employed }\end{array}$ & 91.7 & 48 & 0.032 \\
\hline
\end{tabular}

\subsection{Differences in Optimal Utilization of ANC in the Geo-political Zones}

There was a difference in the proportion of respondents who attained optimal utilisation of ANC in the different zones. Age was found to be significantly associated with optimal utilisation in the northern zones. Respondents aged 35-39 years had the highest proportion of optimal utilisation in the North Central zone (82.2\%), while those aged 15-19 had the least $61.0 \%$. Respondents in urban residence had higher proportions of optimal utilisation of ANC in the North Central (88.8\%), and North West $(71.8 \%)$; however this proportion increased in South West zone (95.7\%).

Wealth index was significantly associated with optimal utilisation across all zones, proportion of respondents increased with increase in wealth index i. e. from the poorest quintile to the richest quintile (North Central: $43.6 \%$ vs. 93.3\%; North East: $65.1 \%$ vs. $80.8 \%$; South East: $73.4 \%$ vs. $97.4 \%$ ). Educational status of the respondents husband/partner was associated with optimal utilisation. In the North East, $60.3 \%$ of those whose husbands had no education attained optimal utilisation compared to $71.5 \%$ of the respondents with educated husbands/partners. This pattern was similar in the South West zone however with slightly higher proportion of $87.5 \%$ vs. $95.6 \%$ for not educated and educated respectively. (Table 2)

Table 2. Factors associated with optimal utilisation in the geo-political zones

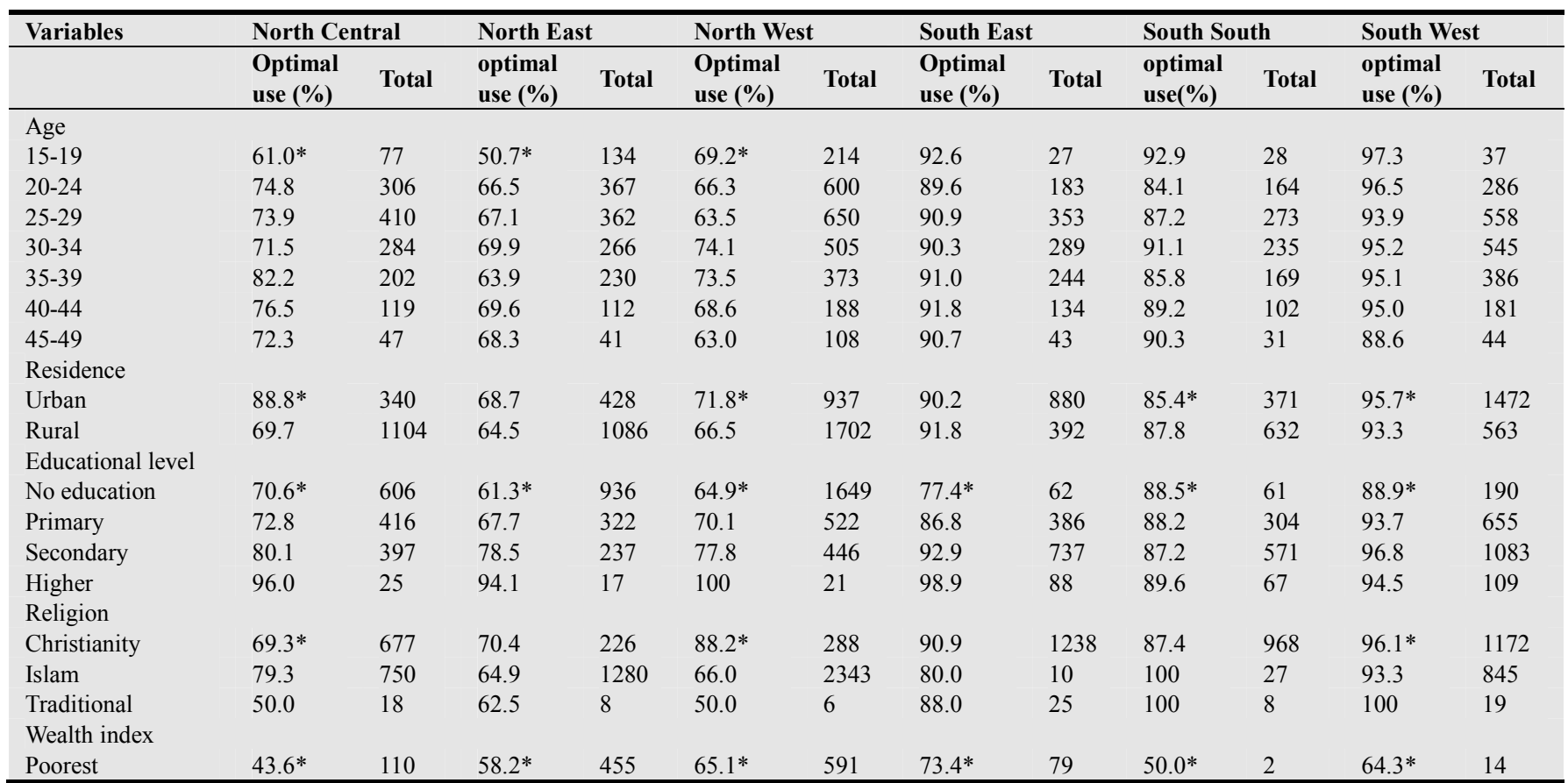




\begin{tabular}{|c|c|c|c|c|c|c|c|c|c|c|c|c|}
\hline \multirow[t]{2}{*}{ Variables } & \multicolumn{2}{|c|}{ North Central } & \multicolumn{2}{|c|}{ North East } & \multicolumn{2}{|c|}{ North West } & \multicolumn{2}{|c|}{ South East } & \multicolumn{2}{|c|}{ South South } & \multicolumn{2}{|c|}{ South West } \\
\hline & $\begin{array}{l}\text { Optimal } \\
\text { use (\%) }\end{array}$ & Total & $\begin{array}{l}\text { optimal } \\
\text { use }(\%)\end{array}$ & Total & $\begin{array}{l}\text { Optimal } \\
\text { use (\%) }\end{array}$ & Total & $\begin{array}{l}\text { Optimal } \\
\text { use (\%) }\end{array}$ & Total & $\begin{array}{l}\text { optimal } \\
\text { use(\%) }\end{array}$ & Total & $\begin{array}{l}\text { optimal } \\
\text { use (\%) }\end{array}$ & Total \\
\hline Poorer & 58.5 & 316 & 65.8 & 1445 & 66.1 & 812 & 82.9 & 181 & 88.8 & 89 & 91.8 & 146 \\
\hline Middle & 78.0 & 549 & 70.3 & 503 & 67.0 & 528 & 90.6 & 339 & 85.3 & 279 & 92.0 & 299 \\
\hline Richer & 85.4 & 335 & 68.3 & 279 & 71.7 & 474 & 92.9 & 365 & 86.9 & 358 & 95.5 & 649 \\
\hline Richest & 93.3 & 135 & 88.2 & 208 & 80.8 & 234 & 97.4 & 308 & 87.7 & 275 & 96.4 & 928 \\
\hline \multicolumn{13}{|c|}{ Employment status(respondent) } \\
\hline Unemployed & $69.7^{*}$ & 284 & 74.2 & 621 & 68.4 & 811 & 93.3 & 253 & 87.5 & 184 & 95.8 & 192 \\
\hline Employed & 75.3 & 1160 & 63.3 & 893 & 68.4 & 1827 & 90.1 & 1019 & 87.9 & 819 & 94.9 & 1845 \\
\hline \multicolumn{13}{|l|}{ Ethnicity } \\
\hline Hausa & $58.8^{*}$ & 51 & $70.2 *$ & 389 & 65.9 & 2175 & 86.7 & 15 & $100^{*}$ & 2 & 95.7 & 23 \\
\hline Igbo & 85.7 & 28 & 83.3 & 6 & 93.0 & 43 & 90.8 & 1239 & 91.7 & 121 & 96.8 & 155 \\
\hline Yoruba & 93.0 & 128 & 100 & 5 & 76.7 & 30 & 85.7 & 7 & 100 & 24 & 95.6 & 1521 \\
\hline Others & 72.6 & 1239 & 63.8 & 1114 & 78.7 & 390 & 90.9 & 11 & 86.9 & 855 & 91.1 & 337 \\
\hline \multicolumn{13}{|c|}{ Number of children alive } \\
\hline $0-4$ & 74.9 & 1059 & 65.4 & 1003 & 68.7 & 1765 & $91.1 *$ & 887 & 87.8 & 735 & $95.0^{*}$ & 1662 \\
\hline 5-9 & 72.8 & 378 & 66.0 & 497 & 68.4 & 833 & 90.5 & 379 & 88.2 & 263 & 95.4 & 370 \\
\hline 10 and Above & 55.6 & 9 & 76.9 & 13 & 56.4 & 39 & 50.0 & 6 & 75.0 & 4 & 50.5 & 4 \\
\hline \multicolumn{13}{|c|}{ Place(facility) of ANC } \\
\hline At a home & 81.8 & 11 & 42.9 & 7 & 53.8 & 26 & $82.8 *$ & 58 & 88.7 & 71 & 92.4 & 131 \\
\hline Government & 74.6 & 1123 & 65.7 & 1444 & 68.6 & 2566 & 89.9 & 574 & 87.5 & 763 & 94.8 & 1011 \\
\hline Private & 72.3 & 311 & 69.8 & 63 & 66.7 & 45 & 92.3 & 640 & 88.7 & 168 & 95.5 & 895 \\
\hline \multicolumn{13}{|c|}{ Husband's/partner's educational level } \\
\hline No education & $62.1^{*}$ & 380 & $60.3^{*}$ & 773 & $63.9^{*}$ & 1252 & $82.9^{*}$ & 76 & 77.8 & 36 & $87.5^{*}$ & 176 \\
\hline Educated & 78.6 & 1065 & 71.5 & 740 & 72.5 & 1387 & 91.2 & 1196 & 88.2 & 967 & 95.6 & 1861 \\
\hline \multicolumn{13}{|c|}{ Husband's/partner's employment status } \\
\hline unemployed & 100 & 10 & 75.0 & 4 & 77.8 & 9 & 100 & 3 & 100 & 15 & 100 & 6 \\
\hline employed & 74.1 & 10 & 65.7 & 1510 & 68.4 & 2629 & 90.7 & 1269 & 87.7 & 988 & 94.9 & 2030 \\
\hline
\end{tabular}

*Statistically significant at 0.05 .

\subsection{Logistic Regression Results}

Respondents from the North East geopolitical zone were less likely than respondents from the North Central zone to have optimal utilisation of ANC (OR=0.50, 95\% CI: 0.455 , 0.557). Similarly North West respondents were less likely to attain optimal utilisation of ANC (OR=0.34, 95\% CI: 0.309, 0.370), (Table 3).

Table 3. Region as a Predictor of ANC Optimal Utilisation.

\begin{tabular}{lllll}
\hline Variable & OR & p-value & $\mathbf{9 5 \%}$ CI & \\
\hline & & & Lower bound & Upper bound \\
\hline North Central $^{\mathrm{a}}$ & & & & \\
North East & 0.50 & $<0.001$ & 0.455 & 0.557 \\
North West & 0.34 & $<0.001$ & 0.309 & 0.370 \\
South East & 4.85 & $<0.001$ & 4.137 & 5.687 \\
South South & 1.62 & 0.001 & 1.435 & 1.836 \\
South West & 6.73 & $<0.001$ & 5.843 & 7.758 \\
\hline
\end{tabular}

(a: reference category).

Respondents aged 35-39 years were more likely to attain optimal utilisation of ANC compared to those aged 15-19 years $(\mathrm{OR}=1.50,95 \% \mathrm{CI}: 1.152,1.946)$. Optimal utilisation of ANC differed with respect to geo political zones. Respondents in South East, South South and South West zones were 2, 2 and 3 times $(\mathrm{OR}=1.77,95 \% \mathrm{CI}: 1.123$, 2.808; $\mathrm{OR}=1.73,95 \% \mathrm{CI}: 1.351,2.207$; $\mathrm{OR}=3.20,95 \% \mathrm{CI}$ : $2.353,4.309)$ respectively more likely to attain optimal utilisation of ANC than North Central zone. Respondents with secondary and higher educational levels were 1 and 2 times $(\mathrm{OR}=1.28,95 \% \mathrm{CI}: 1.071,1.532 ; \mathrm{OR}=1.96,95 \% \mathrm{CI}$ : $1.140,3.353)$ more likely than those with no education to attain optimal utilisation of ANC respectively. Respondents who belong to the richest wealth quintile were about 3 times more likely to attain optimal utilisation $(\mathrm{OR}=2.86,95 \% \mathrm{CI}$ : $2.162,3.775)$ compared to respondents in the poorest quintile, (Table 4).

Table 4. Socio Demographic Characteristics as Predictors of ANC Optimal Utilisation.

\begin{tabular}{|c|c|c|c|c|}
\hline Variables & OR & p-value & $95 \% \mathrm{CI}$ & \\
\hline & & & $\begin{array}{l}\text { Lower } \\
\text { bound }\end{array}$ & $\begin{array}{l}\text { Upper } \\
\text { bound }\end{array}$ \\
\hline \\
\hline $20-24$ & 1.11 & 0.352 & 0.890 & 1.388 \\
\hline $25-29$ & 1.06 & 0.570 & 0.856 & 1.327 \\
\hline $30-34$ & 1.41 & 0.005 & 1.107 & 1.787 \\
\hline $35-39$ & 1.50 & 0.003 & 1.152 & 1.946 \\
\hline $40-44$ & 1.62 & 0.001 & 1.203 & 2.180 \\
\hline $45-49$ & 1.46 & 0.044 & 1.010 & 2.094 \\
\hline \multicolumn{5}{|l|}{ Region } \\
\hline \multicolumn{5}{|l|}{ North Central $^{\mathrm{a}}$} \\
\hline North East & 0.92 & 0.391 & 0.771 & 1.107 \\
\hline North West & 1.00 & 0.997 & 0.815 & 1.227 \\
\hline South East & 1.77 & 0.014 & 1.123 & 2.808 \\
\hline South South & 1.73 & $<0.001$ & 1.351 & 2.207 \\
\hline South West & 3.20 & $<0.001$ & 2.353 & 4.309 \\
\hline \multicolumn{5}{|l|}{ Residence } \\
\hline \multicolumn{5}{|l|}{ Urban $^{\mathrm{a}}$} \\
\hline Rural & 1.14 & 0.065 & 0.992 & 1.320 \\
\hline \multicolumn{5}{|l|}{ Educational level } \\
\hline No education ${ }^{\mathrm{a}}$ & & & & \\
\hline Primary & 1.02 & 0.818 & 0.879 & 1.178 \\
\hline Secondary & 1.28 & 0.007 & 1.071 & 1.532 \\
\hline Higher & 1.96 & 0.015 & 1.140 & 3.353 \\
\hline Religion & & & & \\
\hline
\end{tabular}




\begin{tabular}{|c|c|c|c|c|}
\hline Variables & OR & p-value & $95 \% \mathrm{Cl}$ & \\
\hline & & & $\begin{array}{l}\text { Lower } \\
\text { bound }\end{array}$ & $\begin{array}{l}\text { Upper } \\
\text { bound }\end{array}$ \\
\hline \multicolumn{5}{|l|}{ Christianity $^{\mathrm{a}}$} \\
\hline Islam & 1.05 & 0.603 & 0.879 & 1.250 \\
\hline Traditional & 1.02 & 0.953 & 0.572 & 1.811 \\
\hline \multicolumn{5}{|l|}{ Wealth index } \\
\hline \multicolumn{5}{|l|}{ Poorest $^{\mathrm{a}}$} \\
\hline Poorer & 1.17 & 0.041 & 1.006 & 1.368 \\
\hline Middle & 1.53 & $<0.001$ & 1.288 & 1.819 \\
\hline Richer & 1.83 & $<0.001$ & 1.489 & 2.248 \\
\hline Richest & 2.86 & $<0.001$ & 2.162 & 3.775 \\
\hline \multicolumn{5}{|l|}{ Employment status } \\
\hline \multicolumn{5}{|l|}{ Unemployed $^{\mathrm{a}}$} \\
\hline Employed & 1.02 & 0.706 & 0.907 & 1.154 \\
\hline \multicolumn{5}{|l|}{ Ethnicity } \\
\hline \multicolumn{5}{|l|}{ Hausa $^{a}$} \\
\hline Igbo & 1.83 & 0.007 & 1.179 & 2.849 \\
\hline Yoruba & 1.89 & $<0.001$ & 1.329 & 2.683 \\
\hline Others & 1.06 & 0.501 & 0.891 & 1.265 \\
\hline \multicolumn{5}{|l|}{ Number of children alive } \\
\hline $5-9$ & 0.89 & 0.114 & 0.764 & 1.029 \\
\hline 10 and Above & 0.49 & 0.006 & 0.290 & 0.813 \\
\hline \multicolumn{5}{|l|}{ Place of ANC } \\
\hline \multicolumn{5}{|l|}{ At a home ${ }^{a}$} \\
\hline Government health facility & 1.27 & 0.175 & 0.898 & 1.807 \\
\hline Private health facility & 1.17 & 0.412 & 0.806 & 1.691 \\
\hline \multicolumn{5}{|l|}{$\begin{array}{l}\text { Husband's/partner's } \\
\text { educational level }\end{array}$} \\
\hline \multicolumn{5}{|l|}{ No education ${ }^{\mathrm{a}}$} \\
\hline Educated & 1.38 & $<0.001$ & 1.209 & 1.567 \\
\hline \multicolumn{5}{|l|}{$\begin{array}{l}\text { Husband's/partner's } \\
\text { employment status }\end{array}$} \\
\hline $\begin{array}{l}\text { Unemployed }^{\mathrm{a}} \\
\text { employed }\end{array}$ & 037 & 0076 & 0125 & 1108 \\
\hline
\end{tabular}

(a: reference category).

\section{Discussion}

Optimal utilisation of ANC is very important as a woman will attain maximum care from at least four visits; this is referred to as the Focused Antenatal Care (FANC).

In our study we found different predictors of optimal utilisation of ANC in the different zones. The southern geopolitical zones had higher optimal utilization of ANC compared to the northern zones. The seeming higher socio economic characteristics such as wealth status and educational status of women residing in the southern zones compared to those in the northern zones were found to affect the optimal utilisation of ANC; this is similar to results obtained from [16], which found geopolitical zones to be a factor that affects maternal healthcare service utilisation. Religious and cultural practices are vastly different and these have been found to affect utilisation of healthcare facilities, ANC visits inclusive.

There was a noticeable difference in optimal utilisation between the different age groups with older respondents attending ANC visits more than younger respondents. This finding agrees with the reports of a similar study in South Western, Nigeria [12]. Similarly [10], found women aged greater than twenty-five years utilized ANC more than those less than twenty-five years old and this is similar to results found in our study where older women attained optimal utilization of ANC more than younger women. This may be due to more knowledge about the advantages of ANC by the older women compared to their younger counter parts as they may have had previous births.

Education is a key factor in the utilisation of healthcare in general $[9,6,15]$. Educating the girl child in the northern zones is not considered essential as a result of socio cultural practices and religious beliefs. Similarly, a previous report from North Central Nigeria [4] showed maternal education to be a predictor of ANC service utilisation in North Central Nigeria. Our study found higher level of education improved optimal utilization of ANC. Educated women are more likely to be aware of the benefits of optimal utilization and are likely to be empowered to make decisions about their health.

Social structure affects ANC utilisation; through communication at social gathering, women talk to their peers and discuss about different features of life including health related issues [23]. With increase in wealth, there was increase in the proportion of women who utilized ANC visits. Several studies [24, 25] have linked wealth of women to utilisation; possibly because higher socio economic status is associated with higher education and employment. This enables hospital bills to be paid as more often than not bills are paid out of pockets due to poor state of health insurance in the country.

\section{Conclusion}

In conclusion, several factors were found to affect the optimal utilization of ANC in Nigeria and regional differences occur as well with women in South East, South West and South South utilizing ANC more than those in North East, North West and North Central. The most affected zones are the North East and North West. Measures to improve utilisation of ANC should address the following issues: education of females and regional specific programmes targeting better utilisation of ANC among women should be improved particularly in the Northern part of Nigeria.

\section{References}

[1] National Population Commission Nigeria and ICF Macro, Nigeria Demographic and Health Survey 2008, Abuja, Nigeria. National Populaton Commission and ICF Macro, 2009. Available at: http://nigeria.unfpa.org/pdf/nigeriadhs2008.pdf.

[2] World Health Organisation, World Health Report - Make every Mother and Child count, 2005. Available at: http://www.who.int/whr/2005/en/.

[3] World Health Organisation, "Maternal Mortality ratio (per 100 000 live births)". Health Statistics and Health Information Systems, 2013 pp. 1. Available at: http://www.who.int/healthinfo/statistics/indmaternalmortality. 
[4] K. R. Adewoye, I. O. Musah, O. A. Atoyebi and O. A. Babatunde, "Knowledge and utilisation of antenatal care services by women of child bearing age in Ilorin-East local government area, North Central Nigeria," International Journal of Science and Technology 2013 vol. 3pp. 188-193.

[5] O. A. Onasoga, J. A. Afolayan and B. D. Oladimeji, "Factors influencing utilisation of antenatal care services among pregnant women in Ife Central Lga, Osun State and National Hospital Abuja, Nigeria," Advances in Applied Science Research, 2012 vol. 3 pp. 1309-1315.

[6] O. A. Onasoga, T. A. Osaji, O. A. Alade and M. C. Egbuniwe, "Awaresness and Barriers to Utilisation of Maternal Healthcare Services among Reproductive Women in Amassoma Community, Bayelsa State," Inernational Journal of Nursing and Midwifery, 2014 vol. 6 pp. 10-15.

[7] R. Onoh, O. Umerora, U. Agwu, H. Ezegwui, P. Ezeonu and A. K. Onyebuchi, "Pattern and determinants of antenatal booking at Abakaliki southeast Nigeria". Annals of Medical and Health Sciences Research, 2012 vol. 2, pp. 169-75.

[8] O. U. J. Umeora, B. N. Ejikeme, S. I. Adeoye and R. N. Ogu, "Implementing the new WHO antenatal care model: voices from end users in a rural Nigerian community," Nigerian Journal of Clinical Practice 2008 vol. 3 pp. 260.

[9] U. W. Ibor, O. A. Anjorin, A. E. Ita, M. A. Out and T. I. Bassey, "Utilisation of antenatal care in Ibadan North Local Government Area, Oyo state, Nigeria," Trends in Medical Research 2011 vol. 6 pp. 273-280.

[10] M. D. Dairo and K. E. Owoyokun, "Factors affecting the utilisation of antenatal care services in Ibadan, Nigeria," Benin Journal of Postgraduate Medicine, 2010 vol. 12 pp. 3-13.

[11] V. Awusi, E. Anyanwu and V. Okeleke, "Determinants of Antenatal Care Services UtilisationInEmevor Village, Nigeria,” Benin Journal of Postgraduate Medicine, 2009 vol. 11 .

[12] D. A. Adekanle and A. I Isawumi, "Late Antenatal Care Booking and Its Predictors among Pregnant Women in South Western Nigeria," Online Journal of Health and Allied Sciences, 2008 vol. 7 pp. 1-6.

[13] A. M. Amosu, A. M. Degun, A. M. Thomas, M. F. Olanrewaju, A. O. Babalola, P. E. Omeonu, et al. "A Study on the Acceptance and Practice of Focused Antenatal Care by Healthcare Providers in the South-West Zone of Nigeria," Archieves of Applied Science research, 2011 vol. 3 pp. 484 491.

[14] M. N Sambo, G. A Abdulrazaq, A. F. Shamang and A. A.
Ibrahim, "Household cost of antenatal care and delivery services in a rural community of Kaduna state, Northwestern Nigeria," Nigerian Medical Journal: Journal of the Nigeria Medical Association, 2013 vol. 54 pp. 87-91.

[15] E. O. Nwosu, N. E Urama and C. Uruakpa, "Determinants of Antenatal Care Services Utilisation in Nigeria," IISTE Journal of Developing Country Studies, 2012 vol. 2 pp. 4152 .

[16] S. H. Adamu, Utilisation of Maternal Health Care Services in Nigeria: An Analysis of Regional Differences in the Patterns and Determinants of Maternal Health Care Use, 2011. Available at: http://mph/MPH_Quantitative_Dissertation_.

[17] D. N. Ononokpono and C. O. Odimegwu, "Determinants of Maternal Health Care Utilisation in Nigeria: a multilevel approach," Pan African Medical Journal, 2013 vol. 17.

[18] C. A. Brown, B. S. Sohani, K. Khan, R. Lilford and W. Mukhwana.,"Antenatal Care and Perinatal Outcomes in Kwale District, Kenya,” BMC pregnancy and childbirth, 2008 vol. 8 pp. 2.

[19] J. Ekabua, K. Ekabua and C. Njoku, "Proposed Framework for Making Focused Antenatal Care Services Accessible: A Review of the Nigerian Setting," Obstetrics and Gynecology, 2011 pp. 1-5.

[20] L. Melhado, "The Physical Accessibility of Health Facilities Strongly Affects Haitian Women's Use of Prenatal, Delivery Care,” International Family Planning Perspectives, 2007 vol. 33 pp. 38-43.

[21] Federal Ministry of Health Nigeria Technical Report - 2012 National HIV/AIDS and Reproductive Health Survey, 2013. Available at: http://www.nigeria-aids.org.

[22] World Health Organisation. Antenatal Care Randomized Trial: Manual for the Implementation of the New Model, Geneva: WHO 2002. Available at: http://whqlibdoc.who.int/hq/2001/WHO_RHR_01.30.pdf.

[23] M. S. Kulkarni and M. R. Nimbalkar. "Influence of SocioDemographic Factors on the Use of Antenatal Care," Indian Journal of Preventive Social Medicine, 2008 vol. 39 pp. 2-6.

[24] N. Nisar and F. White. "Factors affecting utilisation of antenatal care among reproductive age group women (15-49 years) in an urban squatter settlement of Karachi". The Journal of the Pakistan Medical Association, 2003 vol. 53 pp. $47-53$.

[25] G. Shrestha, "Factors related to utilisation of antenatal care in Nepal: A generalized linear approach," Journal of Kathmandu College, 2013 vol. 2 pp. 69-74. 